\title{
AN EXPLORATION OF THE RELATIONSHIP BETWEEN MODERN FOREIGN LANGUAGE (MFL) TEACHERS AND COMPUTER ASSISTED LANGUAGE LEARNING (CALL)
}

\author{
Louise Hanna, Dr. David Barr, Dr. Helen Hou and Shauna McGill \\ School of Education, Ulster University, UK
}

\begin{abstract}
A study was carried out with 33 teachers of Modern Foreign Languages (MFL) to obtain information on the interaction of classroom professionals with Computer Assisted Language Learning (CALL) and digital technologies in Second Language (L2) education. MFL teachers were recruited through Facebook groups in the UK. Research subjects were asked to fill out a questionnaire with CALL-specific statements. Significantly, participants recognised a gap in practice versus the expectation of CALL in the MFL classroom. Overall, participants were shown to be interested adopted and daily users of CALL who appreciated its ease and importance for teaching and learning in L2 pedagogy.
\end{abstract}

\section{KEYWORDS}

Computer Assisted Language Learning (CALL), Modern Foreign Languages (MFL), teacher attitudes, digital technologies, Second Language (L2) pedagogy, Second Language Acquisition (SLA), online learning, teacher perceptions, English as a Foreign Language (EFL).

\section{INTRODUCTION}

The role of Computer Assisted Language Learning (CALL) has been of interest to researchers for over four decades (Zou \& Thomas, 20191). Momentous changes and alterations have taken place in this field of research as digital technologies continue to evolve and change. Crucially, the global COVID-19 epidemic has strengthened the centrality of digital technology and CALL in Second Language Acquisition (SLA). To understand their relationship with CALL during this period of significant disruption to education, the study was conducted in the summer of 2020 with 33 Modern Foreign Language (MFL) teachers in the UK. Overall, a short questionnaire was designed to gain insight and further information about how MFL teachers comprehend the significance, value, and ease of CALL in their own pedagogical practices. Therefore, this study focused on the behavioural approach of MFL teachers to CALL within the challenging circumstances of COVID-19.

Simply put, CALL refers to the adoption of diverse technological tools, digital devices and online platforms for the purpose of SLA (Rahimi, 20152). The interdisciplinary subject of CALL has progressed rapidly in line with the continued innovation of digital tools and Computer Aided Technologies. However, the onset of the Coronavirus outbreak marked the beginning of a very substantial and radical change in the teaching and learning landscape, as teachers had to embrace the challenges of online learning (Dhawan, 20203). Nonetheless, the degree to which teachers have successfully mastered these obstacles remains uncertain (König, Jäger-Biela \& Glutsch, 202044). This, therefore, provides the rationale for this small-scale analysis to be conducted with 
International Journal on Integrating Technology in Education (IJITE) Vol.9, No.4, December 2020

in-service MFL classroom practitioners in the UK. Although theoretically a precursor to a more in-depth investigation, the distributed questionnaire was able to provide a rudimentary understanding of the MFL teacher alliance with CALL and digital technologies at a time of crisis in schooling and beyond.

\section{RELATED WORK}

An area of considerable research concern has been the huge global transition to online and distance learning in 2020. During the COVID-19 pandemic, an exploration of the attitudes of Mathematics teachers showed that classroom professionals expressed supporting opinions and optimistic attitudes towards the involvement of digital technologies and technical resources for teaching and learning purposes (Marpa, 20215). In fact, a Finnish study showed that teachers responded quickly to learning new technologies and viewed distance education as straightforward, with the exception of the quality of student interactions (Niemi \& Kousa, 20206). Teachers of English as a Foreign Language (EFL) had diverse impressions of online teaching and learning during COVID-19 in comparison to the traditional face to face modality (Gao \& Zhang, 20207). In Iran, English teachers showed positive expectations of CALL participation for students at home while in lockdown (Khatoony \& Nezhadmehr, 20208). Overall, this research was inspired to reveal the attitudinal perspectives of MFL teachers in the UK context towards the implementation of CALL and computer technologies. In reality, examining the viewpoints of teachers, especially in the midst of a pandemic is crucial for their professional development and pedagogical practice (Zhang, 20209).

\section{Methodology}

A plea for participation was issued on various MFL teaching Facebook pages. Research subjects were asked to complete a short questionnaire comprising of CALL specific statements. This type of research technique aimed to empirically elicit reactions from participants relating to their CALL beliefs. Therefore, this snapshot of the views of teachers about the role of emerging technologies in MFL was based on a positivist approach. This implies that the questionnaire's results are unable to account for the complexity and multiplicity of teacher cognitions in the implementation of CALL in L2 pedagogy. Instead, the findings provide a summary of the MFL teacher relationship with CALL that could be more extensively explored by a large-scale analysis.

\section{FINDINGS}

Firstly, $21.1 \%$ of participating MFL teachers stated that they had more than twenty-years of teaching experience. Interestingly, the highest participation rate derived from relatively new MFL teachers who had between one to five years of teaching and learning experience in the L2 classroom (24. 2\%) (Table 1).

Table 1: A table showcasing the number of years' of MFL teaching by participants.

\begin{tabular}{|l|l|}
\hline Years' of teaching experience & Percentage $\mathbf{( \% )}$ \\
\hline Less than 1 year & 6.1 \\
\hline 1-5 years & 24.2 \\
\hline 6-10 years & 18.2 \\
\hline 11- 15 years & 15.2 \\
\hline 16- 20 years & 15.2 \\
\hline+20 years & 21.1 \\
\hline
\end{tabular}


Such newly or recently qualified teachers may still be transitioning from their teacher education course to the authenticity and realism of the MFL classroom. This may be noticeable in the divide between CALL learning in Initial Teacher Education (ITE) programmes and its tangible application as a fully qualitied teacher in MFL (Woolfolk \& Margetts, 201210). 78.8\% of participants acknowledged that there was a gap between school expectations and actual CALL utilisation (Figure 1).

IS THERE A DIFFERENCE IN EXPECTATION VERSUS PRACTICE OF CALL?

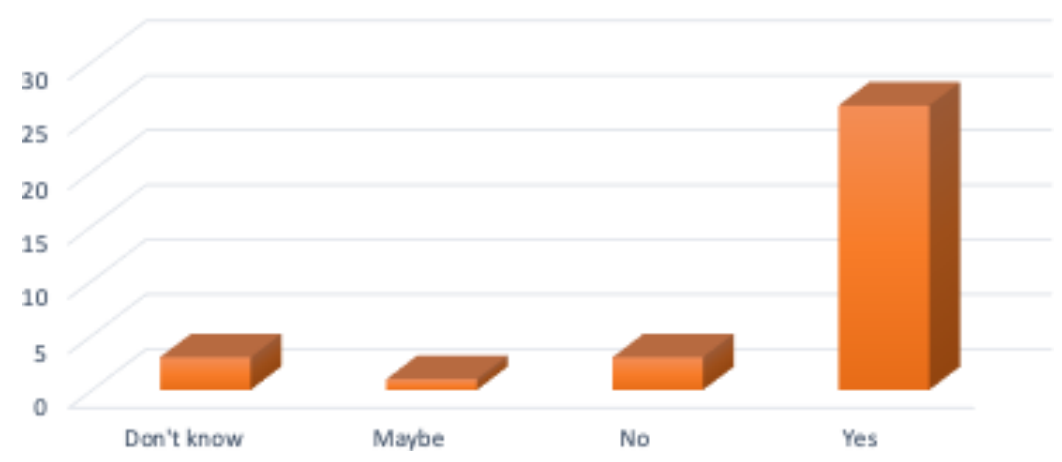

Figure 1: A bar chart demonstrating the gap between expectation and practice of CALL adoption by MFL teachers.

This divergence in CALL realisation is especially pronounced in literature; researchers have continually pointed to the mismatch in the aspirations versus classroom practice of CALL (ClarkWilson, Robutt \& Sinclair, 201411; Kobayashi, 2008: 10512). This gap in CALL intentions and definite teacher usage has been linked to a multitude of significant factors, including the digital skillset of classroom participants, problems in accessing technological resources, difficulties in attaining learning objectives with CALL and a general deficient of CALL education for teachers (Visvizi, 201913). The political landscape of CALL and the influence of policy in education has also widened the conflict between expectations and actual engagement with CALL. Therefore, this investigation has evidenced that more than three quarters of research participants crave a reconciliation between estimated and concrete CALL practice (Vrasidas et al., 200614).

Nevertheless, an interesting point to make is that the variance between expectation and tangible CALL usage is not simply characteristic of lack of interest in online technologies from the MFL teacher viewpoint. The questionnaire evidenced that $24.2 \%$ of research participants were extremely interested consumers of CALL while $33.3 \%$ noted that they were very interested in the interdisciplinary field. The pie chart of Figure 2 presents these findings visually. This result has been validated in other investigations; for example, Lytras and Lytras conveyed that $70 \%$ of teachers were enthusiastic adopters of CALL and digital technologies in their own pedagogy (Lytras \& Lytras, 201015). This contrasts to negative commentary directed towards teacher as being old-fashioned and archaic in their classroom practice of computer technologies (Selwyn, 201616). As a result, this too could be a further subject of interest for future studies in an effort to better understand the rapport teachers experience with CALL. 


\section{INTEREST OF MFL TEACHERS TO CALL}

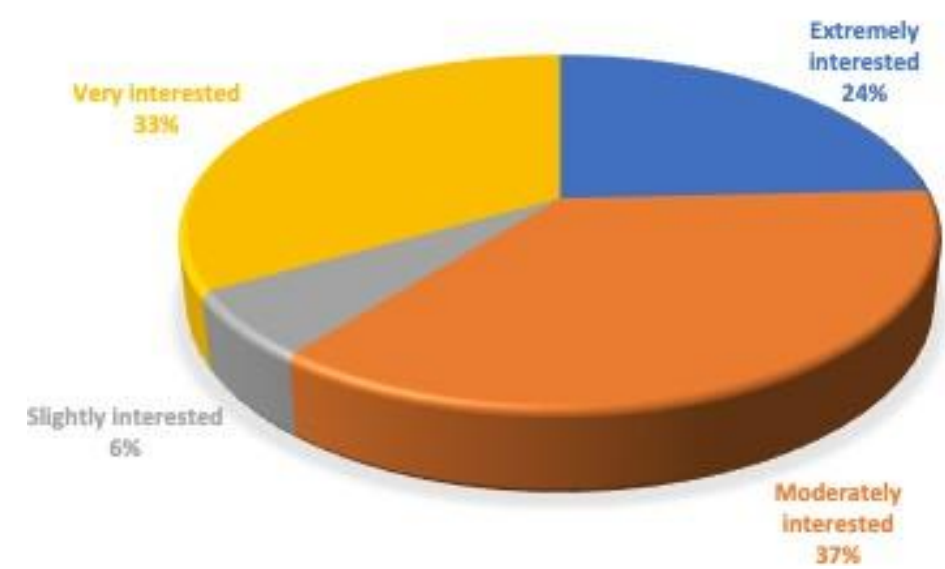

Figure 2: A pie chart showing the level of interest by MFL teacher participants to CALL.

Importantly, the small-scale study not only evidenced that teachers are interested users of computer technologies, but also that CALL is not an overly challenging feat for classroom practitioners (Lin, Zhang \& Zheng, 201717). Interestingly, more than two-thirds of participants confidently conceded that CALL implementation is either extremely or somewhat easy (Figure 3).

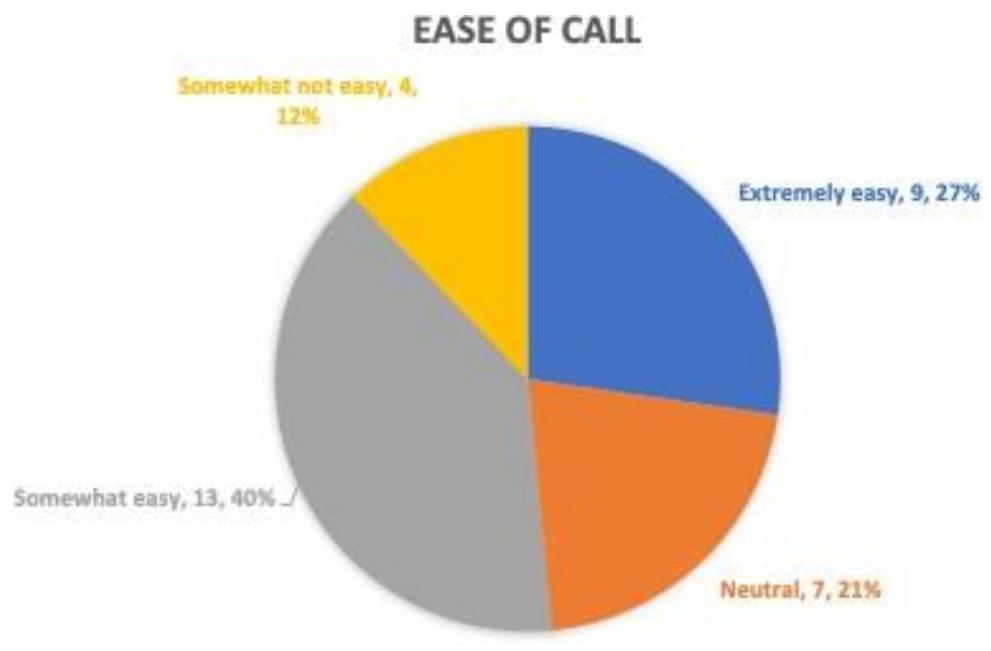

Figure 3: The perceived ease of CALL from the opinion of MFL teachers.

This perception held around the ease of CALL by participating MFL teachers challenges the idea put forth in research that its use is a perplexing and challenging feat (Gibson \& Baek, 200918; Kidd, 200819). Time and time again, CALL has been presented as a difficult and testing endeavour for MFL instructors to successfully implement in the classroom (Carreira et al., 201820). Nevertheless, it is important to recognise that heightened technological sophistication has made equalled with increased ease of use (Haghi \& Luppicini, 201021). In fact, one participant commented that CALL application resembles a 'fish in water'. Such an allegory offers an image of CALL as a seemingly simple and natural experience for MFL instructors. Therefore, the questionnaire's findings support the perception that the gap in CALL implementation may be smaller than previously envisaged. In reality, one third of MFL teachers contributing to the study 
International Journal on Integrating Technology in Education (IJITE) Vol.9, No.4, December 2020

were adamant that they utilised CALL tools and techniques each and every lesson. These findings are presented in Table 2 .

Table 2: A table presenting the frequency of CALL usage by participating MFL instructors.

\begin{tabular}{|c|c|}
\hline Frequency of CALL usage & Percentage (\%) \\
\hline Always (every lesson) & 33.3 \\
\hline Never (not use) & 6.1 \\
\hline Often (every other lesson) & 30.3 \\
\hline Rarely (once a term) & 6.1 \\
\hline Sometimes (once a month) & 24.2 \\
\hline
\end{tabular}

This offers positive confirmation that MFL classroom practitioners are regularly drawing upon CALL as a foundation of their L2 pedagogical practice (Bain \& Weston, 201222). In this way, CALL has become a normalised phenomenon for both teachers and pupils, akin to paper and paper in the learning process. In fact, this state of normalisation had been predicted years earlier; it had been anticipated that CALL would be a fundamental mechanism of the experience

of language learning (Torsani, 201623). Such daily and everyday application of CALL can be associated with a positive perception of the role of computerised technologies on the part of the research participants. Research investigations have showcased the link between belief formulation and actual CALL implementation (Torsani, 201623). In reality, the attitudes of teaching practitioners to CALL has been evaluated as a key factor relating to their technological behaviours (Brown \& van der Merwe, 201525). The positive beliefs of the questionnaire participants were particularly pronounced in this small-scale study. Figure 4 emphasises that $37 \%$ of MFL instructors assessed CALL as extremely important and $33 \%$ as very important. This displays how research participants were highly appreciative of the power of computer technologies for both them and their language learners (Pahomov, 201426). This has been particularly substantiated in the findings of this investigation which is also limited in its empirical character. Hence, the MFL teacher participants of this small-scale examination have presented a predominantly positive attitude to CALL that directly correlates to their application of computer technologies in the L2 classroom (Ball et al., 201827).

Beyond the statistical evidence amassed, one question within the data collection instrument enabled a greater explanation and further detail from research participants. Contributing MFL teachers offered a more varied picture of the effectiveness of CALL than in the closed, limited questions of before. The feedback offered by participants to the question What one sentence best describes your experiences with CALL/ technology as a teacher of MFL? is displayed in Table 3. 
International Journal on Integrating Technology in Education (IJITE) Vol.9, No.4, December 2020

Table 3: The experiences that participants have had with CALL.

\begin{tabular}{|c|c|}
\hline Positive & Negative \\
\hline It is essential to the modern age. & In need for direction. \\
\hline $\begin{array}{l}\text { An enriching and exciting experience for me } \\
\text { and my students. }\end{array}$ & Frustratingly hard. \\
\hline I believe it to be effective. & $\begin{array}{l}\text { I have sometimes felt overwhelmed by options } \\
\text { out there. }\end{array}$ \\
\hline $\begin{array}{l}\text { Enhances research skills and wider cultural } \\
\text { knowledge. }\end{array}$ & Restricted due to poor equipment at school. \\
\hline $\begin{array}{l}\text { I am a proactive innovator, so I am always } \\
\text { willing to undertake new challenges and } \\
\text { options in my pedagogy. }\end{array}$ & $\begin{array}{l}\text { Labour intensive and not always worth the } \\
\text { effort. }\end{array}$ \\
\hline $\begin{array}{l}\text { Essential, invaluable, key to developing all } 4 \\
\text { skills. }\end{array}$ & Equality of access still presents as an issue. \\
\hline $\begin{array}{l}\text { Teaching in an iPad school has opened my } \\
\text { eyes to so many ways of incorporating } \\
\text { technology into learning in a meaningful way. }\end{array}$ & $\begin{array}{l}\text { Lack of face to face teaching and feedback } \\
\text { must be taken into account. }\end{array}$ \\
\hline Good for independent study. & $\begin{array}{l}\text { During lockdown and being an MFL teacher } \\
\text { was very different to being an IT expert. }\end{array}$ \\
\hline $\begin{array}{l}\text { I feel that we use it more than other subjects in } \\
\text { secondary schools. }\end{array}$ & Doesn't always work. \\
\hline It is invaluable in the digital age. & Don't want to use it. \\
\hline I'm trying my best to use it. & Frustrating. \\
\hline An extremely helpful tool. & $\begin{array}{l}\text { There are too many assumptions made about } \\
\text { the knowledge and skills of students when } \\
\text { using technology. }\end{array}$ \\
\hline $\begin{array}{l}\text { It allows me to be able to reach all students and } \\
\text { abilities. }\end{array}$ & Potentially boring for students with repetition \\
\hline $\begin{array}{l}\text { I love sourcing Spanish and French cultural news } \\
\text { to share with pupils on a monthly basis. }\end{array}$ & Can be a disaster when network issues arise. \\
\hline Great potential. & $\begin{array}{l}\text { It is extremely challenging to teach the intricacies } \\
\text { of language (grammar / verbs etc.) } \\
\text { online. }\end{array}$ \\
\hline Very willing to learn. & Students not as motivated \\
\hline $\begin{array}{l}\text { CALL provides an extra way of teaching and } \\
\text { learning that most learners enjoy and use for } \\
\text { personal study. }\end{array}$ & Overrated. \\
\hline $\begin{array}{l}\text { Fabulous way to get students to practise repetitive } \\
\text { skill tasks, to share documents and information } \\
\text { with classes in class and at home, great for } \\
\text { enabling students to work at own pace in online } \\
\text { tasks while I can do individual } \\
\text { oral tasks with small groups etc. }\end{array}$ & \\
\hline
\end{tabular}

Nevertheless, 33. 3\% of research participants were especially encouraging of CALL to student teachers. Their one piece of advice to teachers in training was to actively engage CALL in their pedagogical practice (Figure 5). 


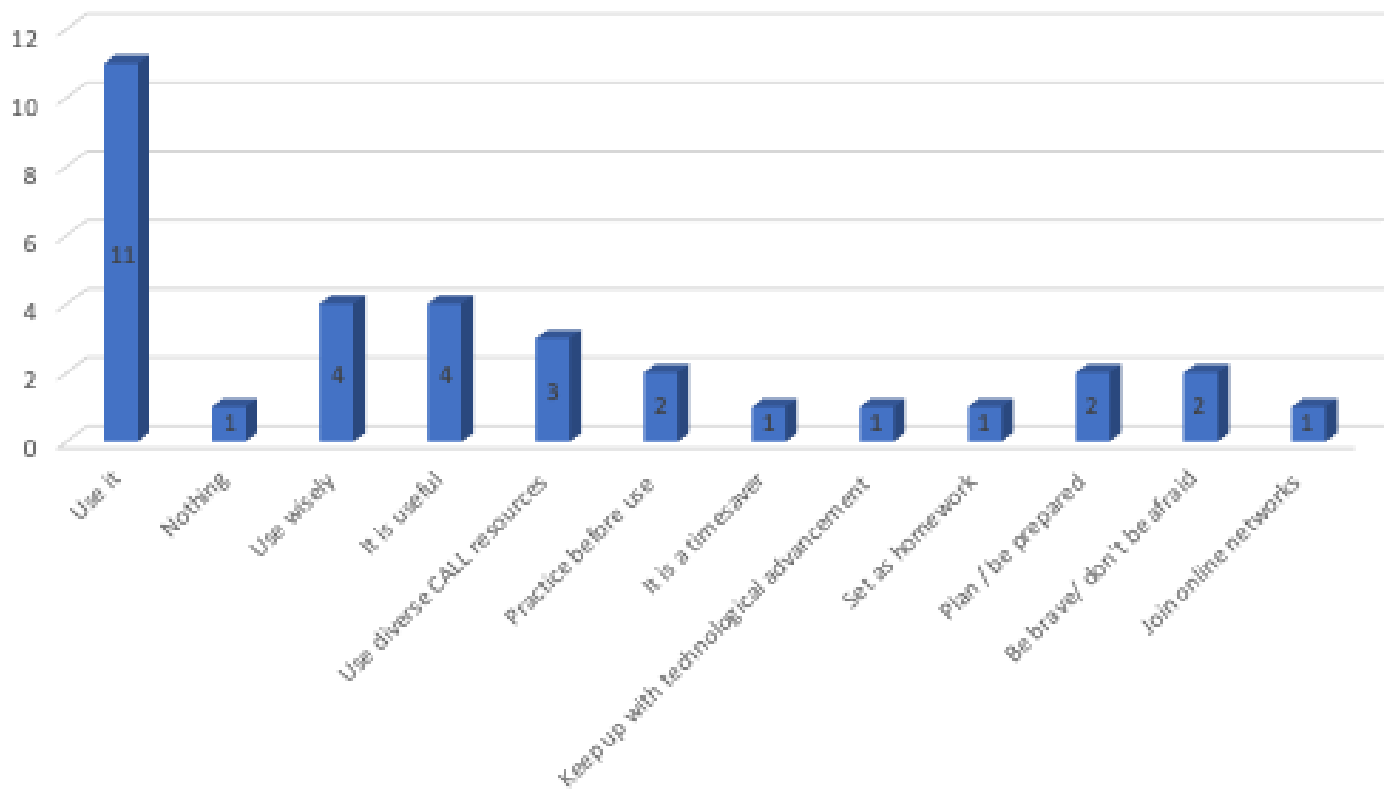

Figure 5: A bar chart signifying the advice of MFL teachers to student teachers.

This kind of advice indicates that this sample of MFL instructors had been broad- minded and enthusiastic in encouraging teachers in training to include the possibilities of CALL in their L2 classroom. This has been reinforced in research scrutinising limitations to CAL realisation. The readiness of MFL instructors to exploit the potentials of CALL and computer technologies has been prevented by a plethora of economic, external or situation barriers (Schul, 201928; Underwood \& Farrington-Flint 201529). One MFL teacher respondent commented that CALL was only feasible 'if laptops, iPads and computer rooms are available'. This highlights that CALL is influenced by the political panorama of education and the role of Local Education Authorities (LEA). One contributor commented that 'as decision-making stakeholders, they are the ones deciding budgets and priorities for communities'. The global Coronavirus health crisis has reinforced the significance of the General Data Protection Regulation (GDPR) and privacy in Zoom video calls. Hence, CALL and digital technology usage is the result of a broad assortment of collaborative elements. This study has presented a general overview of how MFL instructors interact with the world of CALL. As a result, further studies would be welcome as a means to more comprehensively understand the rapport between MFL teachers and computer technologies.

\section{Limitations AND FUtURE RESEARCH}

A considerable issue related to this investigation is that it was concentrated on a positivity methodology. This inherent limitation could have been compensated by switching to alternative research method, such as, a qualitative or mixed-methods approach. This opens to the door to further research studies to be undertaken on the subject of the MFL instructor relationship with CALL. Additionally, this investigation was based on the perceptions of a small sample of 33 inservice MFL teachers. A larger number of research participants would have allowed for more rigorous of the MFL instructor alliance with CALL to be made. Follow-up studies could embody a longitudinal appreciation of how MFL instructors experience CALL over a longer period of time. Further analysis could be undertaken with MFL student teachers to obtain their perspective of CALL during a programme of Initial Teacher Education (ITE). 
International Journal on Integrating Technology in Education (IJITE) Vol.9, No.4, December 2020

\section{Conclusions}

Finally, this investigation has offered an overview of how MFL instructors relate to CALL in the L2 teaching and learning environment. In a positive sense, participants were presented as regular adopters and everyday consumers of CALL. However, the cognitions of MFL teachers pointed to a divergence in the expectation versus reality of CALL usage in SLA. This is in spite of an evident interest and sense of ease in the application of computer technologies on the part of questionnaire respondents. In fact, contributing MFL instructors were keen to promote CALL to the next generation of student teachers. Nevertheless, this study is limited in its quantitative methodological approach and small sample size. In spite of this inherent issue, this study set out to present a glimpse of how MFL teachers comprehend CALL amid the worldwide

COVID-19 pandemic. As a consequence, the research can be drawn upon as a means to conduct supplementary investigations into how classroom practitioners interact with CALL.

\section{REFERENCES}

[1] Zou, B. \& Thomas, M. (2019). Recent Developments In Technology-Enhanced \& Computer-Assisted Language Learning, Hershey: IGI Global, pp. xv.

[2] Rahimi, M., (2015). Handbook of research on individual differences in computer-assisted language learning, Hershey, PA: Information Science Reference, an imprint of IGI Global, pp. 45.

[3] Dhawan, S. (2020). Online Learning: A Panacea in the Time of COVID-19 Crisis. Journal of Educational Technology Systems, 49(1), 5-22. Available online: https://doi. org/10. $1177 / 0047239520934018$

[4] König, J. Jäger-Biela, D. J. \& Glutsch, N. (2020) Adapting to online teaching during COVID-19 school closure: teacher education and teacher competence effects among early career teachers in Germany, European Journal of Teacher Education, 43:4, 608-622. Available online: https://doi. org/10. 1080/02619768. 2020. 1809650

[5] Marpa, E. P. (2021). Technology in the teaching of mathematics: An analysis of teachers' attitudes during the COVID-19 pandemic. International Journal on Studies in Education (IJonSE), 3(2), 92102. Available online: https://doi. org/10. 46328/ijonse. 36

[6] Niemi, H. M., \& Kousa, P. (2020). A case study of students' and teachers' perceptions in a Finnish high school during the COVID pandemic. International Journal of Technology in Education and Science (IJTES), 4(4), 352-369. Available online: https://doi. org/10. 46328/ijtes. v4i4. 167

[7] Gao, L. X \& Zhang, L. J. (2020). Teacher Learning in Difficult Times: Examining Foreign Language Teachers' Cognitions About Online Teaching to Tide Over COVID-19. Front. Psychol. 11:549653. Available online: https://doi. org/10. 3389/fpsyg. 2020. 549653

[8] Khatoony, S., \& Nezhadmehr, M. (2020). EFL teachers' challenges in integration of technology for online classrooms during Coronavirus (COVID-19) pandemic in Iran. AJELP: Asian Journal of English Language and Pedagogy, 8, 1-16. Available online: https://doi. org/10. 37134/ajelp. vol8. sp. 1. 2020

[9] Zhang, C. (2020). From Face-to-Face to Screen-to-Screen: CFL Teachers' Beliefs about Digital Teaching Competence during the Pandemic. International Journal of Chinese Language Teaching, 1(1), 35-52. Available online: https://doi. org/10. 46451/ijclt. 2020. 06. 03

[10] Woolfolk, A \& Margetts, K. (2012). Educational Psychology, third edition. Frenchs Forest, NSW, Australia: Pearson Australia, pp. 7.

[11] Clark-Wilson, A. Robutti, O. \& Sinclair, N. (2014). The Mathematics Teacher in the Digital Era. An International Perspective on Technology Focused Professional Development. Dordrecht: Springer, pp. 11.

[12] Kobayashi, R. (2008). New educational technology. New York: Nova Science Publishers, pp. 105.

[13] Visvizi, A., (2019). The future of innovation and technology in education policies and practices for teaching and learning excellence, United Kingdom: Emerald Publishing, pp. 116.

[14] Vrasidas, C. et al. (2006). Preparing teachers to teach with technology. Greenwich Conn: Information Age Publishing, pp. 366. 
International Journal on Integrating Technology in Education (IJITE) Vol.9, No.4, December 2020

[15] Lytras, M. D. \& Lytras, M. D. (2010). Technology Enhanced Learning: Quality of Teaching and Educational Reform: 1st International Conference, TECH-EDUCATION 2010, Athens, Greece, May 19-21, 2010. Proceedings. Berlin, Heidelberg: Springer Berlin Heidelberg, pp. 462.

[16] Selwyn, N., (2016). Education and technology: key issues and debates, New York: Bloomsbury Academic, pp. 127.

[17] Lin, C. -H. Zhang, D. \& Zheng, B. (2017). Preparing foreign language teachers for next-generation education. Hershey, PA: Information Science Reference (an imprint of IGI Global), pp. 32.

[18] Gibson, D. \& Baek, Y. (2009). Digital simulations for improving education: learning through artificial teaching environments, Hershey, PA: Information Science Pub, pp. 428.

[19] Kidd, T. (2008). Handbook of research on instructional systems and technology, Hershey, PA: Information Science Reference, pp. 227.

[20] Carreira, S. et al., (2018). Youngsters Solving Mathematical Problems with Technology \#x98; The Results and Implications of the Problem\#x9C; Web Project, Cham: Springer International Publishing, pp. viii.

[21] Haghi, A. K. \& Luppicini, R., (2010). Cases on digital technologies in higher education: issues and challenges, Hershey, PA: IGI Global, pp. 214.

[22] Bain, A. \& Weston, M. E. (2012). The learning edge: what technology can do to educate all children. New York: Teachers College Press, pp. xi.

[23] Torsani, S., (2016). CALL teacher education: language teachers and technology integration, Rotterdam: Sense Publishers, pp. 55.

[24] Eshetu, G. (2015). Factors Affecting Instructional Leaders Perception towards Educational Media Utilization in Classroom Teaching. Hamburg, Germany: Ancho, pp. 25.

[25] Brown, T. H. \& van der Merwe, H. J. (2015). The mobile learning voyage - from small ripples to massive open waters: 14th World Conference on Mobile and Contextual Learning, mLearn 2015, Venice, Italy, October 17-24, 2015, proceedings, Cham: Springer, pp. 33/

[26] Pahomov, L., (2014). Authentic learning in the digital age: engaging students through inquiry, Alexandria, VA: ASCD, pp. 9.

[27] Ball, L. Drijvers, P. Ladel, S. Siller, H. -S. Tabach, M. \& Vale, C. (2018). Uses of Technology in Primary and Secondary Mathematics Education: Tools, Topics and Trends. Cham: Springer International Publishing, pp. 416.

[28] Schul, J. E. (2019). Paradoxes of the public school: historical and contemporary foundations of American public education. Charlotte, NC: Information Age Publishing, Inc, pp. 183.

[29] Underwood, J. D. M. \& Farrington-Flint, L. (2015). Learning and the E-Generation. Chichester, West Sussex: John Wiley \& Sons Inc, pp. 156.

\section{AUTHORS}

Louise Hanna is a second year $\mathrm{PhD}$ researcher at Ulster University in Northern Ireland. Her interests are extensively centred on the usage of digital technologies in L2 pedagogy. Prior to undertaking her PhD, Louise was a MFL teachers in both England and Northern Ireland.

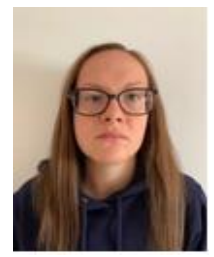

